\title{
RELATIONSHIP BETWEEN HOPE AND PSYCHOLOGICAL WELL- BEING AMONG MALE AND FEMALE STUDENTS OF FARHANGIAN UNIVERSITY OF ZANJAN PROVINCE
}

\author{
Mohammad Saeed Ahmadi \\ Zanjan Farhangian University, Iran \\ E-mail: ghavaghy57@gmail.com \\ Abbas Ramazani \\ Zanjan Farhangian University, Iran \\ E-mail:a_ramezani@sbu.ac.ir
}

Submission: 9/9/2019

Revision: 10/2/2019 Accept: 1/7/2020

\section{ABSTRACT}

The purpose of this study was to determine the relationship between hope and psychological well-being among the students of Farhangian University using a descriptive correlational research method. All students of Farhangian University of Zanjan province in the academic year of 2018-19 were considered and 324 of them were selected as the research sample. Hope scale Schneider (1991) and psychological well-being scale of Ryff (1989) were used as research tools. using SPSS 21 software, Pearson correlation coefficient test, stepwise regression, ANOVA and independent t-test were used to analyze the data. The results showed that there was a significant relationship between hope and psychological well-being and this includes their components too $(p<0.01)$. There is no significant difference between hope and psychological well-being among students based on gender $(\mathrm{P}>0.05)$. Also, the results of stepwise regression indicated that hope and motivational hope could predict psychological wellbeing ( $\mathrm{p}<0.01)$. Therefore, it can be concluded that in order to improve the psychological well-being of students, their hope should be increased in a way.

Keywords: hope, psychological well-being, motivational hope, hope of passage, students 
DOI: 10.14807/ijmp.v11i6.1122

\section{INTRODUCTION}

Health is a dynamic state in which people consistently adapt to changes in the environment, and mental well-being is an important component of health (SANCHEZ et al., 2017). Psychological well-being is a domain of positive psychology and a component of a personal and individual concept that means the cognitive and emotional evaluation of individuals from different domains and aspects of their life (SABZI et al., 2015).

Psychological well-being has two interdependent cognitive and emotional components. The cognitive dimension means the cognitive assessment of individuals from the level of mental health and quality of life and the emotional dimension means having the maximum positive affection and least negative affection (RAJABI; MAGHAMI, 2015). Psychological well-being means the ability to find all the talents of a person, and the balance between positive and negative affection, satisfaction with life, and job and family satisfaction is created (SANCHEZ et al., 2017).

People with a high sense of well-being experience more positive emotions, have a positive assessment of their past, present, and future, and also describe themselves, others and events as pleasant. On the other hand, people with low sense of well-being assess them as inconvenience and experience more negative emotions (JIN, 2014).

Ryff, Keyes and Shmotkin (2002) argues that psychological well-being is a quest for perfection in realizing the real potential of a person. According to this view, psychological well-being means an attempt to promote that manifests itself in the realization of the abilities and person's potential. The goal of psychological well-being is to create mental health and a healthy environment for establishing the right human relationships.

Psychological well-being represents a person's achievement in full psychological capabilities. Psychological well-being has six dimensions: self-acceptance (positive assessment of self and past life itself), personality development (feeling of growth and continuing growth in the person's position), having a goal in life (believing that life is meaningful), positive relationship with Others (having a meaningful relationship with others), environmental domination (the effective management capacity of the individual and the surrounding world) and independence (the individual's sense of his decisions) (STAMP et al., 2014).

Psychological well-being is an area of positive psychology that seeks to examine cognitive (general judgment about life satisfaction) and emotional (the experience of pleasant 
DOI: 10.14807/ijmp.v11i6.1122

and unpleasant emotions) assessment of their lives (BAYAT, 2017) Psychological well-being has two components: cognitive and emotional. Its cognitive component is called life satisfaction. This component covers the person's assessment and judgment of quality of life.

The emotional component includes positive emotion, showing pleasure, having chevron, relaxation, comfort and hope for life. Negative affection is also manifested with restlessness, sadness, anxiety, anger, and feelings of unworthiness and frustration. Therefore, individuals with a psychological well-being, with a sense of life satisfaction, high affection and low negative affection are identified (PAVOT; DIENER, 2008).

Psychological well-being, as one of the main components of public health and satisfaction, has attracted the attention of many psychologists and researchers during the past two decades, and extensive research has been done in this regard (BERGER, 1996; BERGER, 2001; RYFF, KEYES, SHMOTKIN, 2002; RYFF, 1989; WISSING; VAN EEDEN, 1998).

Since psychological well-being is one of the important indicators of mental health, quality of life and life satisfaction, and many factors such as social, personality, emotional, cultural, occupational and other factors are involved in the well-being of individuals, therefore it is necessary that related factors are examined with psychological well-being.

One of the factors associated with psychological well-being is hope. Hope is a positive and planning motivation mode that is the result of an individual's interaction with the environment (ROSE et al., 2012). In fact, hope is an exhilarating factor that enables individuals to choose a path that leads to a positive outcome and a symbol of mental health and the ability to believe in a better feeling in future (SATICI, 2016).

Hope as a healing, dynamic and powerful healer, as one of the sources of coping, plays an important role in adapting to tensions and events (CARRETTA; RIDNER, 2014). Hope as a factor in the richness of life enables individuals to see themselves beyond the current state of view (MOREIRA et al., 2016).

Hope is one of the features of life that makes people look for a better tomorrow. Hope is one of the key issues for creating calmness and improving the human's perplexing life. In positivist psychology, it is believed that structures such as hope can protect individuals from stressful events of life.

Under Schneider's theory of thought, hope is defined as the expectation of a person to succeed in achieving the goal. For Schneider and colleagues, hope is perceived capacity to 
DOI: 10.14807/ijmp.v11i6.1122

generate paths toward desirable goals and perceived motivation to move on these pathways (SNYDER; LOPEZ, 2000).

Hope is having belief in the positive outcome of events or circumstances in life. Hope is an emotion about whether we can have what we want or an event would have the best result for us. Hope is different with being optimistic. Hope is an emotional state; it is one of human emotions, but optimism is the result of a deliberate and optional pattern of thought (insight) that leads to a positive state and behavior in humans. Hope means expecting success and a better future, a reason to live, and there is a passion for life when there is hope in heart and mind.

For Schneider, hope is "perceived ability to produce paths toward pleasing ends, with perceived motivation to use those paths to reach the target" (SNYDER, 2000). In this twofactor framework, the sense of efficiency (or intent) moves toward individual goals and strategies to plan the program and ways to achieve the desired goals (BRYANT; CVENGROS, 2004). Researchers believe that hope is needed to cope with uncertainty and difficulty (PARKINS, 1997).

Enlightenment, vitality, and mental vitality have a significant effect on all aspects of personality and how the different behaviors of a person appears; therefore, in addition to paying attention to personality, paying attention to the sense of well-being or satisfaction of individuals is also necessary and psychological well-being leads to balanced growth And man's health and pave the way for a more correct and wider education of his talents (MORADI; SEYED; ABEDI, 2005).

Students are prone to loss of psychological well-being due to special student circumstances, such as being away from family, getting into a large, tense environment and economical setback, having insufficient income, a large amount of lessons and intensive competitions. Therefore, their psychological well-being is of great importance (MEHRI; SEDIQUI, MONTASERI, 2011).

Evidence indicates that, unfortunately, the problems of today's young generation (such as the prevalence of depression, drug addiction, having high-risk sexual relations, etc.) are much higher than in previous generations, and given that today's youth are owners The future of the community, their health and illness will have significant effects on tomorrow's society's health and future generations; therefore, it is necessary to pay more attention to the psychological and physical health of this massive stratum (SAFAR-ALIZADEH et al., 2014). 
DOI: 10.14807/ijmp.v11i6.1122

Therefore, with regard to the importance of psychological well-being and its related variables in students and researches in this field, the present study was conducted with the aim of determining the relationship between hope and psychological well-being in students of Farhangian University in Zanjan province in the academic year of 2017-18.

\section{RESEARCH METHOD:}

The method of this research is applied in the field of applied research in terms of the purpose. The data collection method is a descriptive correlation type. The statistical population of this study included all male and female students of Farhangian University of Zanjan province in the academic year of 2017-18. The population were consisted of four hundred and fifty one (261 boys and 190 girls) who were not sampled due to the limited nature and accessible population. A total of 324 questionnaires were used and distributed among all members of the statistical population. Finally, after collecting completed questionnaires, 324 questionnaires (191 males and 133 females) were completed and corrected and analyzed.

\section{RESEARCH TOOLS}

1) Hope scale: This scale has been developed by Schneider in 1991 to measure the amount of hope. This scale has 12 items with 8 items to be used and 4 other items related to the passage component. The subject demonstrates an agreement with each item using a five-dimensional scale (completely disagreeing to fully agree). The initial evidence about the validity and reliability of this test was provided by Schneider et al. The Cronbach's alpha was between 0.74 and 0.84 , and the reliability of its revision was calculated 80 percent over a period of 10 weeks. Kashdan (2002) alpha coefficient for the total scale was reported 0.82 and for the dimensions of the broker and the passage, respectively, were 0.81 and 0.66 . In Iran, the reliability of this scale was performed on 100 students. The Cronbach's alpha coefficient for the component of the broker was 0.71 and 0.67 for the passage. The validity of the scale was calculated by the simultaneous validity method. The simultaneous validity of the Hope scale with the Despair scale of 0.81-1 is reported (ZADEH; MIRJAFARI, 2006). In addition, the validity and reliability of this scale in Iran have been confirmed by Alaeddini, Kajbaf and Molavi (2008).

2) Psychological well-being questionnaire: In the present study, the psychological wellbeing questionnaire of Ryff (1989) was used. This questionnaire has 54 items that have

6 components: self-acceptance, self-determination, purposeful life, positive 
DOI: 10.14807/ijmp.v11i6.1122

relationships with others, environmental mastery and individual growth. How to answer the questions is that the subject must choose in a 6-point range 1) fully agree to 6) fully disagree to indicate to what extent s/he agree or disagrees with any of the terms. The general framework of the questionnaire and the questions related to each variable as well as the related researchers are presented in Table (1).

Table 1: Dimensions of psychological well-being questionnaire

\begin{tabular}{|c|l|l|}
\hline \multicolumn{1}{|c|}{ Variable } & \multicolumn{1}{|c|}{ Dimensions } & \multicolumn{1}{c|}{ Number of items } \\
\hline \multirow{4}{*}{ Psychological well-being } & The sense of autonomy & 9 \\
\cline { 2 - 3 } & Personal growth & 9 \\
\cline { 2 - 3 } & Positive relationships with others & 9 \\
\cline { 2 - 3 } & Purposefulness in life & 9 \\
\cline { 2 - 3 } & Acceptance Agent & 9 \\
\cline { 2 - 3 } & Domination of the environment & 9 \\
\hline
\end{tabular}

The Cronbach's alpha coefficient was 0.95. This means that this questionnaire has a good reliability. In Table 2, the Cronbach's alpha coefficient has been shown for each component.

Table 2: Cronbach's alpha coefficient of research variables

\begin{tabular}{|c|c|c|c|}
\hline Variable & Dimensions & Numer of Question & \multicolumn{2}{|c|}{ alpha coefficient } \\
\hline \multirow{4}{*}{$\begin{array}{c}\text { Psychological } \\
\text { well-being }\end{array}$} & The sense of autonomy & 9 & 0.89 \\
\cline { 2 - 4 } & Personal growth & 9 & 0.89 \\
\cline { 2 - 4 } & Positive relationships with others & 9 & 0.90 \\
\cline { 2 - 4 } & Purposefulness in life & 9 & 0.91 \\
\cline { 2 - 4 } & Acceptance Agent & 9 & 0.86 \\
\cline { 2 - 4 } & Domination of the environment & 9 & 0.86 \\
\hline
\end{tabular}

\section{RESEARCH FINDINGS}

Table 3: Kolmogrov-Smirnov test for normal distribution of research variables

\begin{tabular}{|c|c|c|}
\hline Variable & Kolmogorov statistic & Level of significance \\
\hline Motivational hope & 0.57 & 0.14 \\
\hline Hope for the passage & 1.25 & 0.08 \\
\hline Hope & 0.98 & 0.29 \\
\hline Autonomy & 1.04 & 0.09 \\
\hline Domination of the environment & 1.11 & 0.17 \\
\hline Personal Growth & 0.94 & 0.34 \\
\hline Positive relationships with others & 1.17 & 0.13 \\
\hline Purposefulness in life & 0.93 & 0.36 \\
\hline Self-acceptance & 0.85 & 0.46 \\
\hline Psychological well-being & 1.01 & 0.26 \\
\hline
\end{tabular}

As shown in Table 3, since the significance level of the test for all variables is greater than $\mathrm{P}<0.05$, Kolmogorov-Smirnov statistics are not meaningful for any of the variables, and thus the assumption of the normal distribution of the data is acceptable. Parametric tests can be used to test the research hypotheses.

Table 4: Levin test for the homogeneity assumption of variances

\begin{tabular}{|c|c|c|c|c|}
\hline Variable & $\begin{array}{c}\text { Levin's } \\
\text { statistic }\end{array}$ & $\begin{array}{c}\text { degree of } \\
\text { freedom 1 }\end{array}$ & $\begin{array}{c}\text { degree of } \\
\text { freedom } 2\end{array}$ & $\begin{array}{c}\text { Level of } \\
\text { significance }\end{array}$ \\
\hline
\end{tabular}


INDEPENDENT JOURNAL OF MANAGEMENT \& PRODUCTION (IJM\&P)

http://www.ijmp.jor.br

v. 11, n. 6, September - October 2020

ISSN: 2236-269X

DOI: 10.14807/ijmp.v11i6.1122

\begin{tabular}{|c|c|c|c|c|}
\hline Motivational hope & 1.42 & 1 & 322 & 0.86 \\
\hline Hope for the pasaage & 1.71 & 1 & 322 & 0.99 \\
\hline Hope & 2.13 & 1 & 322 & 0.67 \\
\hline Autonomy & 0.03 & 1 & 322 & 0.11 \\
\hline Domination of the environment & 0.001 & 1 & 322 & 0.54 \\
\hline Personal Growth & 0.18 & 1 & 322 & 0.37 \\
\hline Positive relationships with others & 2.52 & 1 & 322 & 0.85 \\
\hline Purposefulness in life & 0.38 & 1 & 322 & 0.68 \\
\hline Self-acceptance & 1.39 & 1 & 322 & 0.19 \\
\hline Psychological well-being & 0.04 & 1 & 322 & 0.14 \\
\hline
\end{tabular}

As shown in Table 4, the significance level obtained in Levin statistic is not significant for any of the variables at the level of $\mathrm{p}<0.05$. Therefore, with $95 \%$ confidence, it can be said that the homogeneity assumption of variances for all variables is observed.

Table 5: Pearson correlation coefficients and significant levels between hope and psychological well-being

\begin{tabular}{|c|c|c|c|c|c|c|c|c|}
\hline \multicolumn{2}{|c|}{ Variables } & \multirow{2}{*}{$\begin{array}{c}\begin{array}{c}\text { Autono } \\
\mathrm{my}\end{array} \\
* * 0.27\end{array}$} & \multirow{2}{*}{ 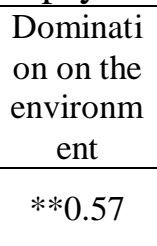 } & \multirow{2}{*}{$\begin{array}{c}\begin{array}{c}\text { Person } \\
\text { al } \\
\text { growt } \\
\text { h }\end{array} \\
* * 0.40\end{array}$} & \multirow{2}{*}{$\begin{array}{l}\text { Positive } \\
\text { relations } \\
\text { hip with } \\
\text { others } \\
* * 0.38\end{array}$} & \multirow{2}{*}{$\begin{array}{l}\text { purposefuln } \\
\text { ess in life } \\
\quad * * 0.54\end{array}$} & \multirow{2}{*}{$\begin{array}{c}\text { self- } \\
\begin{array}{c}\text { acceptan } \\
\text { ce }\end{array} \\
* * 0.50\end{array}$} & \multirow{2}{*}{$\begin{array}{c}\begin{array}{c}\text { Psychologi } \\
\text { cal well- } \\
\text { being }\end{array} \\
* * 0.60\end{array}$} \\
\hline \multirow{2}{*}{$\begin{array}{c}\text { Motivatio } \\
\text { nal Hope }\end{array}$} & $\begin{array}{c}\text { Correlati } \\
\text { on }\end{array}$ & & & & & & & \\
\hline & $\begin{array}{c}\text { Significa } \\
\text { nce }\end{array}$ & 0.0001 & 0.0001 & 0.0001 & 0.0001 & 0.0001 & 0.0001 & 0.0001 \\
\hline \multirow{2}{*}{$\begin{array}{l}\text { hope the } \\
\text { passage }\end{array}$} & $\begin{array}{l}\text { Correlati } \\
\text { on }\end{array}$ & $* * 0.29$ & $* * 0.33$ & $* * 0.28$ & $* * 0.25$ & $* * 0.28$ & $* * 0.38$ & $* * 0.21$ \\
\hline & $\begin{array}{c}\text { Significa } \\
\text { nce }\end{array}$ & 0.0001 & 0.0001 & 0.0001 & 0.0001 & 0.0001 & 0.0001 & 0.0001 \\
\hline \multirow{2}{*}{$\begin{array}{l}\text { Hopefuln } \\
\text { ess }\end{array}$} & $\begin{array}{c}\text { Correlati } \\
\text { on }\end{array}$ & $* * 0.36$ & $* * 0.60$ & $* * 0.44$ & $* * 0.43$ & $* * 0.53$ & $* * 0.52$ & $* * 0.64$ \\
\hline & $\begin{array}{c}\text { Significa } \\
\text { nce }\end{array}$ & 0.0001 & 0.0001 & 0.0001 & 0.0001 & 0.0001 & 0.0001 & 0.0001 \\
\hline
\end{tabular}

As shown in Table 5, the Pearson correlation coefficient between hopes and psychological well-being (0.64) is significant at the level of $p<0.01$. Also, Pearson correlation coefficient between psychological well-being $(\mathrm{P}<0.01)$ and motivational hope $(0.60)$ and hope the passage $(0.21)$ are significant.

Also, Pearson correlation coefficient between hope and autonomy components (0.36), environment mastery (0.60), personal growth $(0.44)$, positive relationship with others $(0.43)$, purposefulness in life (53.3) 0) and self-acceptance (0.52) at $\mathrm{P}<0.01$ level. Therefore, with 99\% confidence, we can say that there is a significant relationship between hope and its components, and psychological well-being and its components.

Table 6: A summary of stepwise regression model of hope and its components on psychological well-being

\begin{tabular}{|c|c|c|c|c|c|c|c|}
\hline Step & Predictive variable & Index & $\begin{array}{c}\text { Total } \\
\text { Squares }\end{array}$ & $\begin{array}{c}\text { degree of } \\
\text { freedom }\end{array}$ & $\begin{array}{c}\text { Mean of } \\
\text { squares }\end{array}$ & F & P \\
\hline First & Hopefulness & Regression & 108777.7 & 1 & 108777.72 & 222.8 & 0.001 \\
\hline
\end{tabular}


INDEPENDENT JOURNAL OF MANAGEMENT \& PRODUCTION (IJM\&P)

http://www.ijmp.jor.br

v. 11, n. 6, September - October 2020

ISSN: 2236-269X

DOI: 10.14807/ijmp.v11i6.1122

\begin{tabular}{|c|c|c|c|c|c|c|c|}
\hline & & Remaining & 157224.9 & 322 & 488.3 & & \\
\hline \multirow{2}{*}{ Second } & Hopefulness \& & Regression & 111952.8 & 2 & 55976.4 & 116.6 & 0.001 \\
\cline { 3 - 9 } & Motivational hope & Remaining & 15409.8 & 321 & 479.9 & & \\
\hline
\end{tabular}

As the results of Table 6 show, in the first step, hope is entered into the regression equation and the resulting $\mathrm{F}$ (222.8) is significant at $\mathrm{p}<0.001$ and can predict psychological well-being and in the second step, hope and motivational hope was simultaneously introduced into the regression model and the rate of $\mathrm{F}(96.6)$ was significant at $\mathrm{p}<0.001$ and could predict psychological well-being. Therefore, the regression model is significant in both steps.

Table 7: Summary of statistical characteristics of stepwise regression of hope and its components on psychological well-being

\begin{tabular}{|c|c|c|c|c|c|c|c|c|}
\hline Step & Predictive Variables & $\begin{array}{c}\text { Multiple } \\
\text { coefficient } \\
(\mathrm{R})\end{array}$ & (R2) & $\begin{array}{c}\text { (R2) } \\
\text { Modified }\end{array}$ & $\begin{array}{c}\text { non- } \\
\text { standardized } \\
\text { coefficient (B) }\end{array}$ & $\begin{array}{c}\text { Standardized } \\
\text { coefficient } \\
\text { (Beta) }\end{array}$ & $\mathrm{t}$ & $\mathrm{P}$ \\
\hline First & Hopefulness & 0.64 & 0.41 & 0.40 & 3.85 & 0.64 & 14.93 & 0.001 \\
\hline \multirow{2}{*}{ Second } & Hopefulness & 0.65 & 0.42 & 0.41 & 2.83 & 0.47 & 6.01 & 0.001 \\
\cline { 2 - 7 } & Motivational hope & & & & 1.68 & 0.20 & 2.57 & 0.010 \\
\hline
\end{tabular}

The results of stepwise regression in Table 7 show that in the first step, the standardized coefficient for hope $(\beta=0.64)$ is significant at the level of $\mathrm{p}<0.01$ and can predict psychological well-being. Also, in the second step, the standardized coefficient is significant for hope $(\beta=0.47)$ and motivational hope $(\beta=0.20)$ at the level of $p<0.01$ and can predict psychological well-being. But hope of the passage cannot predict psychological well-being (P> $0.05)$.

Table 8: Independent t test for meaningful difference in mean of hope and psychological well-being among male and female students

\begin{tabular}{|c|c|c|c|c|c|}
\hline Variable & Group & Mean & $\begin{array}{l}\text { degree of } \\
\text { freedom }\end{array}$ & $\mathrm{t}$ & Significance \\
\hline \multirow{2}{*}{$\begin{array}{l}\text { Motivational } \\
\text { hope }\end{array}$} & Girls & 18.54 & \multirow{2}{*}{322} & \multirow{2}{*}{1.41} & \multirow{2}{*}{0.26} \\
\hline & Boys & 19.09 & & & \\
\hline \multirow{2}{*}{$\begin{array}{l}\text { hope of the } \\
\text { passage }\end{array}$} & Girls & 13.95 & \multirow{2}{*}{322} & \multirow{2}{*}{0.46} & \multirow{2}{*}{0.72} \\
\hline & Boys & 14.09 & & & \\
\hline \multirow{2}{*}{ Hopefulness } & Girls & 32.50 & \multirow{2}{*}{322} & \multirow{2}{*}{1.27} & \multirow{2}{*}{0.48} \\
\hline & Boys & 33.18 & & & \\
\hline \multirow{2}{*}{ Autonomy } & Girls & 35.02 & \multirow{2}{*}{322} & \multirow{2}{*}{1.11} & \multirow{2}{*}{0.18} \\
\hline & Boys & 35.79 & & & \\
\hline \multirow{2}{*}{$\begin{array}{l}\text { Domination on } \\
\text { the environment }\end{array}$} & Girls & 35.75 & \multirow{2}{*}{322} & \multirow{2}{*}{0.36} & \multirow{2}{*}{0.23} \\
\hline & Boys & 35.49 & & & \\
\hline \multirow{2}{*}{$\begin{array}{c}\text { Personal } \\
\text { development }\end{array}$} & Girls & 36.01 & \multirow{2}{*}{322} & \multirow{2}{*}{0.69} & \multirow{2}{*}{0.92} \\
\hline & Boys & 35.57 & & & \\
\hline \multirow{2}{*}{$\begin{array}{c}\text { Positive } \\
\text { relationships }\end{array}$} & Girls & 35.15 & \multirow{2}{*}{322} & \multirow{2}{*}{1.32} & \multirow{2}{*}{0.56} \\
\hline & Boys & 34.29 & & & \\
\hline \multirow{2}{*}{$\begin{array}{c}\text { Purposefulness in } \\
\text { life }\end{array}$} & Girls & 39.11 & \multirow{2}{*}{322} & \multirow{2}{*}{1.19} & \multirow{2}{*}{0.16} \\
\hline & Boys & 38.10 & & & \\
\hline \multirow{2}{*}{ Self-acceptance } & Girls & 31.08 & \multirow{2}{*}{322} & \multirow{2}{*}{0.09} & \multirow{2}{*}{0.64} \\
\hline & Boys & 31.01 & & & \\
\hline Woll_hoing & Girls & 212.14 & 327 & 057 & $0 ?$ \\
\hline well-being & Boys & 210.27 & 322 & $0.5 /$ & 0.20 \\
\hline
\end{tabular}


DOI: 10.14807/ijmp.v11i6.1122

As shown in Table 8, the significant coefficient for hope and its components is not significant at $\mathrm{P}>0.05$. Therefore, with $95 \%$ confidence, it can be said that there is no significant difference between hope and its components in male and female students.

Also, the significance coefficient for psychological well-being and its components is not significant at $\mathrm{P}>0.05$. Therefore, with 95\% confidence, we can say that there is no significant difference between psychological well-being and its components in male and female students.

\section{DISCUSSION AND CONCLUSION:}

The results of this study showed that there is a significant relationship between hope and its components, and psychological well-being and its components. This finding is consistent with the findings of Hezarjaribi and Shali (2010), Shenaar-Golan (2017), Pernegar (2004), Aghayosefi and Sharif (2010), Aghayosefi and Sharif (2016), Parvandy et al. (2017), Alaeddini, Kajbaf and Molavi (2008), and Bayat (2017) Is the same.

The results of the research indicate a positive and significant relationship between hope and psychological well-being (HEZARJARIBI; SHALI, 2015). For example, Shenaar Golen (2017) reported that there was a positive and significant relationship between hope and psychological well-being in parents with children with special needs (GOLEN, 2017). Also, Aghayosefi and Sharif (2010) reported that in addition to a meaningful and direct relationship between hope and psychological well-being, the mediating role of hope in the relationship between religion and psychological well-being was confirmed (AGHAYOSEFI; SHARIF, 2010). Pernegar (2004) believes that there is a strong relationship between hope and mental health.

In the study, Aladdin (2008) concluded that the higher the hope component was, depression decreased. In explaining this hypothesis one can say that one of the factors affecting the well-being of students is their degree of hope. That is, if the hope for future increases the level of happiness in individuals would increase as well. Disappointed people do not believe in their abilities and they have an unfavorable future and therefore become disillusioned and passive (HEZARJARIBI; SHALI, 2010).

Happier people avoid the waste of time and slackness; they have an optimistic approach to life and hope for success, and thus they are making more effort (Aghayosefi and Sharif (2010). Hope is one of the features of life that makes people look for a better tomorrow. Hope 
DOI: 10.14807/ijmp.v11i6.1122

means expecting success and a better future, a reason to live, when there is hope in the heart and mind, there will be a passion for life (BAYAT, 2017).

Hope therapy has also been effective in increasing the psychological well-being of the elderly. Thus, educational intervention based on the hope-based approach can be used as an effective intervention in increasing the psychological well-being of individuals (PARVANEH et al., 2015). In other words, based on the findings of this research and the study of past studies, it can be said that with increasing hope, the psychological well-being of students increases.

Also, the results of stepwise regression show that hope and motivational hope can predict psychological well-being. This finding is consistent with the results of Hezarjaribi and Shali (2010), Shenaar-Golan (2017), Safar-Alizadeh et al., (2014), Aghayosefi and Sharif (2010), Asgari and al-Din (2008), Parandy, Moradi and Arefi (2017), Alaeddini, Kajbaf and Molavi (2008), and Bayat (2017).

Parandy, Moradi and Arefi (2017) concluded that in the study of mental health prediction based on hope and religious orientation in female headed families, there was a significant relationship between hope and mental health. There was a direct and significant relationship between external religious orientation and mental health. Regression analysis also indicated that hope and religious orientation together predict $45 \%$ of mental health changes.

Hezarjaribi and Shali (2010) concluded that hopefulness with psychological well-being had a meaningful direct relationship. Also, Asgari and al-Din (2008) concluded that social anxiety with a subjective feeling of well-being had a significant negative relationship, and social hope and social support with a positive subjective feeling had a positive and significant relationship.

In explaining this finding based on the theory of Rose et al. (2012), one can say that people with high hopes are happier and have higher life satisfactory, which will increase their energy levels and their activity. Increasing the level of energy and activity on the one hand leads to doing satisfactory activities and, on the other hand, solves the challenges and crises of life relatively faster. Also, hoping to maintain negative emotions at a low level and promoting positive affection improves the adaptability and satisfaction of the individual's life. As a result, increasing levels of hope increase psychological well-being.

In other words, according to the findings of this research and the study of past studies, it can be said that psychological well-being of students of Farhangian University is predictable 
DOI: 10.14807/ijmp.v11i6.1122

based on their hope. That is, how much people motivate and plan for the goal, and how much they enrich their lives and have a positive outlook for their future.

Also, the results of this study showed that there is no significant difference between hope and its components, and psychological well-being and its components in male and female students. These findings are consistent with the results of studies by Crose et al. (1992), Chow et al. (2007), Wang and Miao (2007), Shokri et al. (2008), and Aghayosefi and Sharif (2010) It is consistent with the results of research by Sheldon and Eliot (1999), and Abbaspour et al. (2006). Studies about the existence of gender differences in psychological well-being have controversial results, suggesting a lack of consensus in the results.

Based on studies and quality experiences of Crose et al (1992), there are differences between the two sexes in many dimensions of well-being. Chow (2007) found in his studies that female students had a higher level of psychological well-being compared to male students. They have a more positive self-concept, a positive relationship with others, and a close relationship with friends and have more academic achievement. Wang and Miao (2007) argue that women and men are different in different aspects of mental well-being. Because different resources of stress and various facilities are available to each sex that causes a difference in their health status.

Also, the findings of Moni'e (2010), Shokri, Daneshvarpour and Askari (2008), and Agha Yousefi and Sharif (2010) showed that there is a significant difference between the two sexes in mental well-being and female students have a higher psychological well-being than males. While some studies such as Sheldon and Eliot (1994) suggest that there is no significant difference between men and women in terms of psychological well-being. Also, the findings of Abbaspour, Farahani and Shahrarai (2006) showed that there was no significant difference between male and female students in terms of psychological well-being. The results of his studies showed that gender is less than $1 \%$ effective in well-being and general satisfaction.

In justifying these contradictory results, it can be said that other factors except gender affect mental well-being and hope that these factors vary in different statistical populations. For example, in the present study, male and female students are in similar situations regarding age, educational status, job prospects and social class. It seems that this factor has led to the fact that, despite the insignificant higher level of psychological well-being and the hope of female students, this difference is not statistically significant.

\section{REFERENCES}


ABBASPOUR, P.; FARAHANI, M. N.; SHAHRARAI, M. (2006) The study of the relationship between perfectionism and self-esteem with well-being in medical students of public universities of Tehran. Third Mental Health Student Seminar. University of Science and Technology: p. 271-266.

AGHAYOSEFI, A.; SHARIF, N. (2010) The Relationship between Thinking Styles and Personal Well-being in High School Students and Pre-University Students in the North of Tehran in the academic year of 2008-2009. Journal of Psychological Studies, v. 6, n. 4, p. 104-86.

ALAEDDINI, Z.; KAJBAF, M. B.; MOLAVI, H. (2008) Analyzing Psychometric Characteristics of the Hope Scale of Adults and Hope in a Specific Area. Master's Degree in Psychology. University of Esfahan. Faculty of Psychology and Educational Sciences.

ASGARI, P.; AL-DIN, H. S. (2008) The relationship between social anxiety, hope and social support with a sense of well-being in postgraduate students of Khouzestan Science and Research Branch. Quantum New Findings in Psychology, v. 3, n. 9, p. 25-36.

BAYAT, H. (2017) Investigating the relationship between optimism, hope and psychological well-being with happiness among male and female students of Zanjan University. Master's Thesis. Azad University of Zanjan Branch.

BERGER, B. G. (1996) Psychological benefits of an active lifestyle: What we know and what we need to know. Quest, v. 48, p. 330-353

BERGER B. G. (2001) 'Feeling good': Mood alteration and meaning in exercise. In Papaioanou A., Goudas M., Theodorakis Y. (Eds.), In the dawn of the new millennium, v. 3, p. 13-15. Proceedings of the 10th World Congress of Sport Psychology, May 28 to June 2, Skiathos, Greece. Thessaloniki: Christodoulidi

BRYANT, F. B.; CVENGROS, J. A. (2004) Distinguishing hope and optimism: Two sides of a coin, or two separate coins? Journal of Social and Clinical Psychology, v. 23, p. 273-302.

CARRETTA, C. M.; RIDNER, S. H. (2014) Dietrich MS. Hope, hopelessness, and anxiety: a pilot instrument comparison study. Arch Psychiatr Nurs., v. 28, n. 4, p. 230-4. DOI: 10.1016/j.apnu.2014.05.005 PMID: 25017555.

CHOW, H. P. (2007) Psychological well-being and suholastic achievement among university students in a chandian prairie city. Soc psycho Educ., v. 10, p. 438-493.

CROSE, R.; NICHOLAS, D. R.; BOBBLE, D. C.; FRANK, B. (1992) Gender and wellness: amultidimentional systems Model for counseling. J counseling Develop, v. 71, p. 149-156.

HEZARJARIBI, J.; SHALI, R. S. (2010) A Survey on the Concept of Social Happiness and Its Effective Factors (Case Study in Markazi Province). Social welfare planning, v. 2, n. 3, p. 72131.

JIN, C. H. (2014) The role of users' motivations in generating social capital building and subjective well-being: The case of social network games. Comp Hum Behav., v. 39, p. 29-38. DOI: 10.1016/j.chb.2014.06.022.

KASHDAN, T. B. (2002) Curiosity and interest. In PETERSON, C.; SELIGMAN, M. E. P. (Eds.), Values in Action (VIA) Classification of Strengths. Manuscript in preparation. senior citizens of the neighborhood of Playa ancha. World Dev Persp. 2017; v. 5, p. 7-9. DOI: 10.1016/j.wdp.2017.02.002 
MEHRI, A.; SEDDIQI, M. (2011) The study of mental health status and its related factors in students of Sabzevar universities in 2009. Journal of Medical Sciences, v. 21, n. 4, p. 298304.

MONI'E, F. M. (2010) Comparison of accountability, cooperation spirit, general health, life satisfaction and academic performance of students of day and night schools in West Azarbaijan province. Quarterly Journal of Educational Innovations, n. 34, p. 61-89.

MORADI, M.; SEYED, E. J.; ABEDI, M. R. (2005) Happiness and Character: Review study. Journal of Cognitive Science, y. 7 n. 2, p. 60-71.

MOREIRA, C. N. O.; MARQUES, C. B.; SILVA, M. A. P.; PINHEIRO, F. A. M.; SALOMÉ, G. M. (2016) Association of sociodemographic and clinical factors with spirituality and hope for cure of ostomized people. J Coloproctol., v. 36, n. 3, p. 162-172. DOI: 10.1016/j.jcol.2016.04.009.

PARKINS, S. Y. (1997) Exploring hope: A Journey with Tanzanian adolescents in a school setting; thesis for the degree of master of Education in counseling psychology, Department of Educational psychology, Edmonton, Alberta.

PARANDI, A.; MORADI, A.; AREFI, M. (2017) Predict mental health based on hope and religious orientation in female headed households. Scientific Journal of Religion and Health, v. 5, n. 2, p. 13-22.

PARVANEH, E.; AZIZI, K.; KARIMI, P. (2015) the effectiveness of hope therapy on increasing the happiness of the elderly. Psychology of Aging, v. 1, n. 1, p. 47-41.

PAVOT, W.; DIENER, E. (2008) The Satisfaction With Life Scale and the emerging construct of life satisfaction. Journal of Positive Psychology, v. 3, p. 137-152.

PERNEGAR, T. V. (2004) Health and happiness in young swiss adults, Quality of care until. Geneva University Hospital, Geneva, Switzerland.

RAJABI, G.; MAGHAMI, E. (2015) Self-compassion as mediator between attachment dimensions with mental wellbeing: a path analysis model. Health Psychol., v. 4, n. 4, p. 83100.

ROSE, S.; ELKIS-ABUHOFF, D.; GOLDBLATT, R.; MILLER, E. (2012) Hope against the rain: Investigating the psychometric overlap between an objective and projective measure of hope in a medical student sample. Arts Psychotherapy, v. 39, n. 4, p. 272-8. DOI: 10.1016/j.aip.2012.04.003.

RYFF, C. D. (1989) Happiness is everything, or is it? Explorations on the meaning of psyc2001hological well-being. Journal of Personality and Social Psychology, v. 57, p. 10691081.

RYFF, C. D.; KEYES, C.; SHMOTKIN, D. (2002) Optimal well-being: The empirical encounter of two tradition. Journal of Personality and social Psychology, v. 82, n. 6, p. 100722.

SABZI, Z.; MANCHERI, H.; ROYANI, Z.; ARYAIE, M.; JAFARI, S.; AHMADI G. (2015) Subjective well-being in nursing and midwifery students of Golestan university of medical sciences. J Res Dev Nurs Midwifery., v. 12, n. 1, p. 76-84.

SAFAR-ALIZADEH, F.; HASHEMLU, L.; BAGHERIE, F.; MOTEAREFI, H. (2014) Survey of prevalence of obsessive-compulsive disorder among university students in Khoy city. Psychiatric Nursing, v. 2, n. 2, p. 13-21. 
DOI: 10.14807/ijmp.v11i6.1122

SATICI, S. A. (2016) Psychological vulnerability, resilience, and subjective well-being: The mediating role of hope. Pers Individ Differ., v. 102, p. 68-73. DOI: 10.1 016/j. paid.2016.06.057.

SHELDON, K. M.; ELLIOT, A. J. (1999) Goal Striving, Need Satisfaction and Longitudinal Well-being: The Self-concordance Model. Journal of Personality and Social Psychology, v. 76, n. 3, p. 482-497. https://doi.org/10.1037/0022-3514.76.3.482

SHENAAR-GOLAN, V. (2017) Hope and subjective well-being among parents of children with special needs. Child Fam Soc Work., v. 22, n. 1, p. 306-16. DOI: 10. 1111/cfs.12241.

SHOKRI, O.; DANESHVARPOUR, Z.; ASKARI, A. (2008) Gender differences in academic performance. The role of character traits. Journal of Behavioral Sciences, n. 2, p. 142-127.

SNYDER, C. R. (2000) The past and future of hope. Journal of Social and Clinical Psychology, v. 19, p. 11-28.

SNYDER, C. R.; LOPEZ, S. J. (2000) Positive psychology, 2nd edn. New York, NY: Oxford University Press.

STAMP, E.; CRUST, L.; SWANN, C.; PERRY, J.; CLOUGH, P.; MARCHANT, D. (2015) Relationships between mental toughness and psychological wellbeing in undergraduate students. Personality and Individual Differences, v. 75, p. 170-4.

WANG, W. L.; MIAO, D. M. (2007) Reaserch review of college student's psychological quality. US-China Educ Rev., v. 4, n. 3, p. 54-60.

WISSING, M. P.; VAN EEDEN, C. (1998) A fortigenic conceptualization and empirical clarification of psychological well-being. In L. Schlebusch (Ed.), South Africa beyond transition: Psychological well-being (p. 379-393). Proceedings of the 3rd annual Congress of the Psychological Society of South Africa. Pretoria: PsySSA.

ZADEH, S. S.; MIRJAFARI, S. A. (2006) The Relationship Between Hope and Stress Coping Strategies among Shiraz University Students. Third Student Mental Health Seminar, p. 112110. 